\title{
PROTECTING THE PROPERTY OF THE MENTALLY ILL: THE JUDICIAL SOLUTION IN NINETEENTH CENTURY LUNACY LAW
}

\author{
Chantal Stebbings*
}

ABSTRACT. The modern legal framework for the protection of the mentally ill was conceived and developed in the nineteenth century. A substantial growth in the numbers of the mentally ill revealed an absence of effective and accessible legal protection for the property of patients with small estates. This challenge was met through the retention and reform of the ancient jurisdiction of the Lord Chancellor in the Lunacy Court as the sole instrument of protection. The judicial solution was adopted in preference to bureaucratic regulation, despite the strong forces of state intervention and the reform of the legal system and its processes.

Keywords: Mental illness; legal history; property; state intervention; lunacy commission; lunacy court.

\section{INTRODUCTION}

Mental illness is a growing burden on modern society and the economy. ${ }^{1}$ Balancing the degree of formal protection imposed on the property and person of the mentally ill against that of personal control, responsibility and independence is a challenge inherent in conceiving and implementing an effective legal framework for the care of this sector of society. Contemporary legal provision and perception in this respect evolved from the legal and administrative frameworks established during the nineteenth century when a new environment for mental illness created new challenges that demanded a response from the legal order. In the first half of the nineteenth century there occurred an unprecedented intersection of two factors - the need for legal safeguards to protect the property of the mentally ill from abuse, and a major increase in the numbers of mentally ill individuals with small properties. This created a significant test for the nineteenth century

* Professor of Law and Legal History, Director of the Bracton Centre for Legal History Research, University of Exeter, UK. The support of the British Academy for this research is gratefully acknowledged. Address for correspondence: Professor Chantal Stebbings, University of Exeter, Law School, Amory Building, Rennes Drive, Exeter EX4 4RJ. Email: C.Stebbings@exeter.ac.uk

${ }^{1}$ NHS Information Centre, Mental Health and Community, Mental Health Bulletin: Fourth Report from Mental Health Minimum Dataset and Annual Returns 2010 (NHS 2011). 
regime of lunacy law. The aim of this article is to explore how this challenge was met, which solution was adopted to address the problem of small estates and, in so doing, to assess the extent to which the Victorian legislature and judicature demonstrated a real commitment to ensuring the protection of the smaller properties of the increasing numbers of middle and working class mentally ill. It examines how, if at all, the mentally ill with small estates were able to establish themselves in a turbulent regime of lunacy law administered by two parallel and distinct systems rife with jurisdictional tensions. It discusses whether the first of these systems, the paternal and esoteric jurisdiction of the Lord Chancellor in lunacy, was appropriate to the new social and economic conditions and whether it was accessible to patients of small property. It queries how far the creation of the second, namely the bureaucratic structure for the management of lunacy, addressed the issue of property ownership and explores the interaction between the state's regulation of lunacy and the jurisdiction of the judicial authorities in this respect at a time when fundamental principles of law in this field of social and legal development were being formulated. By identifying the conflicts and tensions, and examining the imperatives that drove the development of the law to their resolution, this article reveals a new perspective within the growth of the Victorian administrative state, namely the engagement of the judiciary with the movement for state intervention in lunacy in nineteenth century England.

\section{A New EnVironment for Mental Illness}

At the beginning of the Victorian era, the environment of mental illness changed radically, primarily because of the considerable increase in that affliction during that period. One product of modernity, and a tragic and unforeseen consequence of rapid industrialisation, was that the number of individuals recognised by the law as "lunatics" - the contemporary legal term for those individuals who had become of unsound mind but for whom there was at least the possibility of recovery ${ }^{2}$ - rose dramatically. In 1845 the number stood at 25,000 with the figure rising to 77,000 by 1883 and to 124,000 by $1908 .{ }^{3}$ The reasons for this increase were complex. ${ }^{4}$ Not only was the population as a whole growing rapidly, doubling between 1837 and 1901,5 it was ageing.

2 Anthony Highmore, A Treatise on the Law of Idiocy and Lunacy (London 1807, repr. New York, 1979), 1-14.

${ }^{3}$ Report of the Royal Commission on the Care and Control of the Feeble-Minded, House of Commons Parliamentary Papers [hereafter HCPP] 1908 (Cd. 4202) xxix 159, para. 646.

4 Andrew Scull, The Most Solitary of Afflictions: Madness and Society in Britain 1700-1900 (New Haven and London 1993), 334-74; D.J. Mellett, The Prerogative of Asylumdom (New York and London 1982), 47-85.

5 From nearly 14 million in 1837 to over 30 million in 1901 (England and Wales): B.R. Mitchell and P. Deane, Abstract of British Historical Statistics (Cambridge 1962), 6-7. 
Increased life expectancy resulted in a much greater proportion of elderly individuals, many with problems of deteriorating mental faculties that were, for legal purposes, classified as unsoundness of mind. The intensity of industrial and commercial advancement experienced in the nineteenth century changed both working practices and living conditions. Long hours in physically challenging employment conditions, using substances that would only later be regulated once their effect on the nervous system had been understood, and living in often squalid and crowded conditions of extreme poverty with no amenities, contributed to levels of stress and mental illness. Furthermore, the changing demographics resulting from the rapid economic development of the early nineteenth century, notably the migration of labour from the countryside to urban centres, resulted in the breakdown of networks of family support, which consequently, as still today, were not available to mitigate either the effects of the social and economic changes on individuals, nor the burden on the state to care for those afflicted.

The response to this severe social problem was the one that the nineteenth century state adopted with respect to most challenges of this nature, namely the mobilisation of the forces of the state to effect wideranging and often radical social reforms through central regulation expressed in legislation. Adopting the Benthamite process of identification of the social evil, followed by intensive official empirical investigation, reforming legislation and its implementation by an organ of varying degrees of independence from the executive, lunacy was brought within the ambit of state regulation in 1845 . The reforming legislation addressed primarily the certification, detention and protection of the persons of the insane, irrespective of their property. It aimed to end abuse, ensure that insane individuals were admitted only to licensed premises on the correct orders and certificates, ${ }^{6}$ and to provide institutionalised care for the insane poor in public county asylums. ${ }^{7}$ This central government control was effected through a new permanent independent organ of regulation, the Lunacy Commission, whose functions were essentially to inspect, advise and report. ${ }^{8}$

This overthrowing of the old order of essentially private responsibility and the imposition of state control places lunacy reform as part of, and in the context of, a much wider movement of law-making which created the modern administrative state. ${ }^{9}$ The effect of the

\footnotetext{
${ }^{6} 8$ \& 9 Vict. c. 100.

8 \& 9 Vict. c. 126. See J.K. Walton, "Casting out and bringing back in Victorian England: pauper lunatics 1840-70" in W.F. Bynum, Roy Porter and Michael Shepherd (eds.), The Anatomy of Madness: Essays in the History of Psychiatry, vol. 2, (London 1985), 132-46.

${ }^{8}$ See generally D.J. Mellett, "Bureaucracy and Mental Illness: the Commissioners in Lunacy 184590" (1981) 25 Medical History 221.

${ }^{9}$ See generally Oliver MacDonagh, A Pattern of Government Growth 1800-60 (London 1961).
} 
interventionist, centralist and increasingly collective legislation of the mid nineteenth century ${ }^{10}$ was actively to transform a number of key areas of everyday life where the social challenges were so great that the continuous, uniform and authoritative control of the state was accepted as the only solution. Accordingly reforms in areas such as working conditions, poverty, public health and education ${ }^{11}$ were to lead to what has been called a revolution in government. ${ }^{12}$ The eighteenth century ideals of laissez-faire, minimal central government, robust localism and a pervasive paternalism gave way to centralised agencies controlling and regulating major areas of activity that had hitherto been purely domestic matters. The nature, chronology and relative weight of the factors, influences and priorities that combined in a highly complex way to achieve this result have been the subject of scholarly debate and dissent for over a hundred years. ${ }^{13}$ While the necessity for legislation as the only effective agent for reform of evident social problems was widely accepted, there has been little consensus as to the contribution of practices, experience, ideas and individuals to the processes and outcomes of this legislative activity.

In the context of lunacy, its regulation by the state was primarily an institutional, necessary and pragmatic response to the continuing appalling conditions many lunatics endured and the growth in their numbers. ${ }^{14}$ As such it sits comfortably within the MacDonagh model of government growth, ${ }^{15}$ but it was justified and sustained by the interplay of complex ideological forces. ${ }^{16}$ The potency of laissez-faire, ${ }^{17}$ slowing or limiting the interventionist process in other fields, ${ }^{18}$ proved

${ }^{10}$ See Michael Hill, The State, Administration and the Individual (London 1976), 23-9; J.B. Brebner, "Laissez Faire and State Intervention in Nineteenth Century Britain" (1948) 8 Journal of Economic History Supplement 59; M.W. Thomas, "The Origins of Administrative Centralisation" (1950) 3 Current Legal Problems 214; Carol Harlow and Richard Rawlings, Law and Administration, 2nd ed., (London 1997), ch. 1.

${ }_{11}$ Raymond Cocks, "Statutes, Social Reform and Control" in W. Cornish, J. Stuart Anderson, Raymond Cocks, Michael Lobban, Patrick Polden and Keith Smith, The Oxford History of the Laws of England, vol. 13, (Oxford 2010), 473-99; 525-79.

12 MacDonagh, Government Growth, p. 320.

${ }^{13}$ See A.V. Dicey, Lectures on the Relation between Law and Public Opinion in England during the Nineteenth Century, 2nd ed., (London 1940); Oliver MacDonagh, Early Victorian Government 1830-1870 (London 1977); David Roberts, Victorian Origins of the British Welfare State (Hamden, Connecticut 1969); Derek Fraser, The Evolution of the British Welfare State, 2nd ed., (Basingstoke and London 1984); William C. Lubenow, The Politics of Government Growth (Newton Abbot 1971); Henry Parris, Constitutional Bureaucracy (London 1969); Kim Lawes, Paternalism and Politics (Basingstoke and New York 2000); David Roberts, "Jeremy Bentham and the Victorian Administrative State" (1959) 2 Victorian Studies 193-210. See too Cocks, "Statutes, Social Reform, and Control", pp. 467-72; 598-620.

${ }_{14}$ Mellett, "Bureaucracy and Mental Illness", p. 242.

15 Oliver MacDonagh, "The Nineteenth-Century Revolution in Government: A Reappraisal” (1958) 1 The Historical Journal 52.

${ }^{16}$ W. Cornish, "Insanity and Mental Deficiency" in Cornish and others, Oxford History of the Laws of England, vol. 13, pp. 823-34.

${ }^{17}$ Roberts, Victorian Origins, pp. 315-26. See generally Arthur J. Taylor, Laissez-faire and State Intervention in Nineteenth-century Britain, Studies in Economic History (London 1972).

${ }^{18}$ For example, the early statutory regulation of factories and the new Poor Law of 1834. 
no barrier in lunacy as it had manifestly failed in relation to the care of the mentally ill and adherents to the doctrine admitted that state intervention was acceptable in order to care for a section of the public too weak to protect itself. ${ }^{19}$ Nor was the demand for local autonomy a hindrance or limiting factor, ${ }^{20}$ for though still highly valued by the Victorians, it was diffused by making it integral to the administrative solution in that justices of the peace both built and managed the county asylums prescribed by the reforming legislation. Against this background, and with a tendency to public apathy in relation to lunacy, the positive forces of pragmatism in the face of social need, moral desirability, and humanitarian and Evangelical imperatives, ${ }^{21}$ the latter forcibly expressed by champions of the cause such as Lord Shaftesbury, ensured the far reaching intervention of the state in the regulation of lunacy.

The extent of property ownership of individual lunatics was clearly as varied as in the rest of the population. All strata of society included unfortunate individuals who had lost their sanity as it was then conceived. From the middle of the nineteenth century the great majority of the lunatic population consisted of the mentally ill received into public institutionalised care as a result of reception orders made on the certificates of medical practitioners and a justice of the peace. Such patients were popularly known as 'certified' or pauper lunatics. Not all of these were paupers in the strict legal sense of being in receipt of parish relief. It was rather that their insanity made it impossible for them to continue to earn their living and so could not afford treatment in a private asylum. It is a striking feature of Victorian lunacy law that the fact that an individual was in immediate need of this kind of treatment and could not afford it, sufficed to bring that person within the meaning of pauper for the purposes of the lunacy legislation. ${ }^{22}$ The overall growth of the lunatic population brought with it an increase in the numbers of mentally ill individuals who were possessed of small capital fortunes or modest incomes and many who were not wealthy but were able to pay for care in a private asylum or the private wing of a state pauper asylum. The annual reports of state asylums and the records of private asylums reveal a significant proportion of professional persons, skilled craftsmen, shopkeepers, farmers, clergymen, army and naval officers, and their wives or widows, among their patients. ${ }^{23}$ Official reports

19 John Stuart Mill, Principles of Political Economy, People's Edition, (London 1891), ch. 11, 575-91.

${ }^{20}$ Tensions between localism and state intervention pervaded all areas of social reform and was a potent limiting factor. See, for example, the new Poor Law: Cocks, "Statutes, Social Reform, and Control", pp. 482-85.

${ }^{21}$ Mellett, "Bureaucracy and Mental Illness", pp. 222-24; Kathleen Jones, Lunacy, Law and Conscience 1744-1845 (London 1955), 66-68.

${ }^{22} 53$ Vict. c. 5, s. 18.

${ }^{23}$ See e.g. the annual reports of the Surrey Lunatic Asylum 1843-1850: London Metropolitan Archives [hereafter LMA] H46/SP/A/02/001-2. 
suggest that such individuals often possessed small estates, of perhaps $£ 500$ or $£ 1000$ in capital value, yielding between $£ 50$ and $£ 100$ income a year, or annual incomes of up to about $£ 200 .{ }^{24}$ Although as individuals they were rarely wealthy, collectively they were worth some $£ 1$ million per annum, produced by a capital sum of several millions. ${ }^{25}$ The numbers of such lunatics of small estate had hitherto been insufficiently large to be distinguished or identified as a class in its own right, but in the mid nineteenth century they constituted a newly emergent social construct that now required the specific and explicit protection of the law.

\section{THE JURISDICTION OF THE LORD CHANCELLOR}

The need to protect the property of the mentally ill from unscrupulous friends, family and professional advisers was not an insight new to the Victorians. It was a necessity that had always been recognised. Ideally the patient was maintained by advances from friends or relatives, a course that problems of capacity and title made desirable. Where this was not possible the patient's property was managed by his relatives as well as they could, though this was inevitably difficult, irregular and haphazard. In practice, they usually managed the property genuinely for the patient's benefit, did not defraud him and used it properly to ensure he was looked after and his estate was preserved. However there were no sanctions if this obligation, which was no more than a moral duty, was disregarded. Abuse was common and ranged from expenditure which was not strictly for the benefit of the patient, to downright fraud and theft, a practice that was easy where ready cash and disposable chattels were concerned. It was also well known that many lunatics were given very small allowances by their families, even though there was plenty of available income, with the intention that the heir and next of kin would benefit from a larger inheritance. Property was equally vulnerable to dissipation through honest but incompetent management, and there also existed the danger that the mentally ill could dissipate their property through their own lack of judgment. Evidence suggests that such unilateral squandering of money was relatively rare, mainly because members of the individual's family were generally sufficiently interested to interfere at an early stage to prevent it. ${ }^{26}$ The greater danger was the unscrupulous abuse of the mentally ill by third parties outside the family, by "designing persons who plundered"

${ }^{24}$ Minutes of Evidence before the Select Committee on Lunacy Law, HCPP 1877 (C. 373) xiii 1, [hereafter S.C. Lunacy Law 1877] qq. 5773-4.

${ }^{25}$ Further Report of the Commissioners in Lunacy, HCPP 1847-8 (C. 858) xxxii 371 [hereafter Further Report Lunacy 1847-8] 438.

${ }^{26}$ Minutes of Evidence taken before the Royal Commission on the Care and Control of the FeebleMinded, HCPP 1908 (Cd. 4215) xxxv 83 [hereafter R.C. Feeble-Minded 1908 (4215)] q. 2984. 
them. ${ }^{27}$ Undoubtedly, and most importantly, the ownership of substantial property provided a strong motive for improper detention as a lunatic by the family and pecuniary misappropriation, ${ }^{28}$ and a powerful argument for special supervision.

So evident were these dangers that a specialised legal regime to safeguard the property of lunatics was developed early in the history of English law. It was ancient ${ }^{29}$ and derived from the royal prerogative, ${ }^{30}$ the king, as parens patriae, having the right and duty to care for those incapable of looking after themselves, including lunatics. The king delegated this jurisdiction to the Lord Chancellor personally. From 1842 it was exercised in a department quite separate from the Court of Chancery, known variously as the Lunacy Department, Office, or Court, an administrative division that reflected the nature of the jurisdiction itself as distinct from that of Chancery. ${ }^{31}$ The jurisdiction was declared in the statute De Prerogativa Regis in 1324 which stated that the land of a lunatic was to be safely kept and its profits used to maintain him, and that it should be returned to him should he regain his sanity or, if he did not recover, to pass to his heirs on his death. ${ }^{32}$ The king could take nothing for himself from the land.

The inherent jurisdiction of the Lord Chancellor over the property of lunatics was, in legal theory, unlimited and incapable of definition, but had to be exercised for the benefit of the patient. ${ }^{33}$ The property had to be kept safe, protected from risk and hazard, in the interests of the lunatic who owned it. ${ }^{34}$ It was a highly personal and paternalistic jurisdiction, the court aiming to represent the patient himself as far as possible, to "supply the place in society and the state which his withdrawal has rendered void". The court was his "mind and soul" and in its practice it acted as a "prudent and occasionally selfish man of the world"; it was "tentative and unadventurous, open-handed, to avoid probable loss; sparing, to make possible gain; supremely concerned for his own comfort, and disregardful of the interests and expectations of

${ }^{27}$ Ibid., at q. 2985.

${ }^{28}$ Minutes of Evidence taken before the Royal Commission on the Care and Control of the FeebleMinded, House of Commons Parliamentary Papers 1908 (Cd. 4218) xxxvii 455 [hereafter R.C. Feeble-Minded 1908 (4218)] q. 29599. See too Roy Porter, Mind Forg'd Manacles (London 1987), $112-14,148-55$.

${ }^{29}$ H.S. Theobald, The Law Relating to Lunacy (London 1924), iii; Sir F. Pollock and F.W. Maitland, The History of English Law, 2nd ed., vol. 1, (Cambridge 1898 reissued 1968), 481; Sallyanne Payton, "The Concept of the Person in the Parens Patriae Jurisdiction over Previously Competent Persons" (1992) 17 Journal of Medicine and Philosophy 605.

${ }^{30}$ F.W. Maitland, "The 'Praerogativa Regis"” (1891) 6 English Historical Review 367; Theobald, Lunacy, pp. 1-9.

31 James L.J. famously observed that '[U]nsoundness of mind gives the Court of Chancery no jurisdiction whatever': Beall v Smith (1873) L.R. 9 Ch. App. 85, 92.

3217 Edw. II c. 10 (1324). Frances' Case (1537) Moore K.B. 4; Prodgers v Frazier (1684) 3 Mod. 43.

${ }^{33}$ Wellesley $v$ Wellesley (1828) 2 Bli. N.S. 124, 142-3.

${ }^{34}$ Oxenden v Lord Compton (1793) 2 Ves. Jun. 69, 73. 
others". ${ }^{35}$ Throughout the nineteenth century this wide jurisdiction was made more explicit through its declaration in statute. Legislation of $1830^{36}, 1852^{37}$ and $1853^{38}$ permitted the Lord Chancellor to exercise powers well beyond those of mere management, to sell or charge the corpus of the lunatic's estate, whatever his interest, in order to clear debts or to pay any expenditure for his maintenance or otherwise for his benefit. He could sanction the conveyance of land in the performance of a contract, of partnership property, the sale, partition or exchange of land in which the lunatic had an undivided share, the sale or leasing of land for building purposes, the assignment of business premises and the disposition of undesirable leases. The full extent of the Lord Chancellor's powers to manage and administer the property of lunatics was declared in the Lunacy Act $1890 .{ }^{39}$

In their terms, however, the statutory provisions did not limit the Lord Chancellor's protection to any size of estate. Indeed, $D e$ Prerogativa Regis was widely worded to include all lunatics with any amount of property, the wealthy and the modest. But what came to be a material factor in terms of the size of a lunatic's estate was the limitation of the Lord Chancellor's protection under his inherent jurisdiction to those lunatics "so found". A lunatic "so found" was one who had been judged of unsound mind so as to be incapable of governing himself and his affairs by a trial known as an inquisition and he was popularly known as a Chancery lunatic. The process began with a petition by a friend or relative of the alleged lunatic, accompanied by medical evidence. If there was a prima facie case, the judge would order an inquiry to be held by officers of the Lunacy Court with a jury. On a finding of insanity the court would ascertain the extent of the patient's property and income, identify the heir and next of kin and bring the person and property within the court's protection. ${ }^{40}$

The protection resulting from a finding of lunacy by inquisition was highly effective. The judicial authority took an immediate, complete and informed control of the property, acting as its "protector" 41 and "guardian". ${ }^{42}$ The capital was protected in that the lunatic would be unable to make a valid disposition of his property. While an allowance was given to maintain the lunatic, and any surplus paid into the court and invested in Consols to be accumulated to his credit, the day to day management of his property passed to the committee of the estate who

\footnotetext{
${ }^{35}$ H.M.R. Pope, A Treatise on the Law and Practice of Lunacy, 2nd edn., (London 1890), 158.

3611 Geo. IV \& 1 Will. IV c. 65.

3715 \& 16 Vict. c. 48, s. 1.

${ }^{38} 16 \& 17$ Vict. c. 70 , ss. $116,122-134$.

3953 Vict. c. 5 , ss. $116-143$.

${ }^{40}$ For a fully documented inquisition and subsequent proceedings, see LMA ACC/1156/071.

${ }^{41}$ Report of the Select Committee on Lunatics, HCPP 1859 Sess. 1 (C. 204) iii 75 [hereafter S.C. Lunatics 1859], q. 1186.

42 S.C. Lunacy Law 1877, q. 11077.
} 
was a single individual, often a relative, appointed by the court. He was the public expression of the judicial safeguard, because his powers were strictly limited. The property did not vest in him, and with only the power to act as "the legal hand to pay and receive all money", ${ }^{43}$ he was "a mere machine in the hands of the court". ${ }^{44}$ Every payment, sale, lease or repair had to be expressly and formally authorised by the judge following the rigorous consideration of expert evidence from surveyors or valuers that the transaction was appropriate and beneficial to the lunatic. ${ }^{45}$ The utmost care and conservatism characterised the dealings of the Lunacy Court, since it was guided by the principle that if the patient recovered, he would find his estate exactly as it was before he became insane. This preservation of the capital, and the use of the income to support the individual and his dependants, were the prime aims of the court. It was not to protect the capital for the benefit of the heir of the lunatic. Indeed, when it was argued in 1898 that in the exercise of its jurisdiction over property the court should take into account the interests of persons affected other than the lunatic and could not alter their rights, Lindley M.R. responded that "we have nothing to do with that". ${ }^{4}$

\section{INACCESSIBILITY OF THE PROCESS}

While this indisputably effective legal protection of lunatics' property existed, its process was utterly inaccessible to the very great majority of the mentally ill. First, the law itself was so complex and bulky, so technical and so dominated by internal court practices that only those specialising in the field understood it. Solicitors with a general practice and members of the public, even those with a special interest, ${ }^{47}$ were frequently baffled by the obscurity of the legal regime and found it difficult to work out the powers and jurisdiction of the various authorities involved in the regulation and management of the insane.

Secondly, and more significantly, the procedures were expensive. In the first years of the nineteenth century when inquisitions lasted days or even weeks, the daily fees of the court officers, jury members, solicitors and counsel typically amounted to some hundreds of pounds. In the subsequent administration of the lunatic's property by the court the petitions, orders and reports required for any dealing with the property, with supporting affidavit evidence and the joining of all the next of kin represented by their own solicitors at every stage, resulted

${ }^{43}$ S.C. Lunatics 1859 , q. 1147.

${ }_{44}$ Arthur J. Johnes, Suggestions for a Reform of the Court of Chancery (London 1834), 130.

${ }^{45}$ E.g. LMA ACC/1156/041; LMA ACC/1156/56.

46 Re Earl of Sefton (1898) 78 L.T. 765.

${ }^{47}$ See $e . g$. the evidence of the Secretary of the Lunacy Law Amendment Society in S.C. Lunacy Law 1877 , qq. 6923-7019. 
in enormous expense in professional fees for the preparation of the relevant legal instruments. ${ }^{48}$ The system was lengthy, cumbrous and expensive in every case of inquisition, and where litigation was necessary the costs rose astronomically.

So costly was the inquisition process and the protection it entailed, that it was in practice used primarily by wealthy individuals whose estates were sufficiently large to bear the expense and to warrant comprehensive protection, and where the individual was believed to have no hope of recovery. ${ }^{49}$ The evidence shows that some middle class lunatics with small estates used the process ${ }^{50}$ but did so for want of any alternative legal protection, and with a very real danger that it would be at the expense of their entire small fortunes. With Chancery lunatics forming only a tiny proportion of the lunatic population, ${ }^{51}$ it is clear that the majority of the mentally ill possessing small estates were effectively denied the protection of the judicial authority in lunacy and in general did not seek it, even when it was necessary.

This failing of the legal regime was vigorously criticised by lawyers and public alike, but because demands for reform were predicated on the principle that where any lunatic owned property, large or small, it was the duty of the Lord Chancellor to safeguard it, inevitably reforms focussed on the excessive delay and cost of the inquisition proceedings. This did result in reforming legislation, but it was slow and piecemeal. In 1833 it was enacted that the commission in lunacy could be addressed to just one officer of the court, ${ }^{52}$ and a statute of 1842 effected a major improvement when these ad hoc appointees were replaced with two permanent salaried officers, later known as masters in lunacy. ${ }^{53}$ They would be responsible for conducting all the inquiries relating to the lunacy and the property and would take full and informed control of the lunatic's estate. The most significant and effective reforms ${ }^{54}$ of the inquisition process were introduced by Lord St Leonards, who, along with Lord Lyndhurst, was one of the most active and visionary reformers of the lunacy laws. The Lunacy Regulation Act 1853 abolished the compulsory jury to decide on

48 See e.g. the papers associated with the court's supervision of the sale of a lunatic's property in 1880: LMA ACC/1156/56.

${ }^{49}$ See for example the Earl of Sefton: The National Archives [hereafter TNA] C 211/63/31; John Mitchison, the son of a silk merchant: LMA ACC/1156/076. See his inquisition at LMA ACC/ $1156 / 071$.

${ }^{50}$ In the parliamentary return of the yearly incomes of the 514 Chancery lunatics in 1853,216 had incomes under $£ 200$, nearly 200 had incomes ranging from $£ 200$ to $£ 1000$, and some 65 had incomes of over £1,000: HCPP 1852-3 (C. 323) 1xxviii 331. In 1859, out of 600 estates in the Lunacy Court, there were 140 where the incomes were less than $£ 100$, and another 140 where it was between $£ 100$ and $£ 200$ : S.C. Lunatics 1859 , q. 1190 .

51 1.5\% in 1876: S.C. Lunacy Law 1877 , qq. 75-78.

$523 \& 4$ Will. IV c. 36, s. 1 .

$535 \& 6$ Vict. c. 84 , s. 1 .

54 H.L. Deb. ser. 3, vol. 126 cols. 1025-27 (3 May 1853). See generally T.C.S Keely, "One Hundred Years of Lunacy Administration" (1942-44) 8 C.L.J. 195. 
unsoundness of mind ${ }^{55}$ and restructured the fees system in favour of small estates, ensuring the cost of the court administration of property was defrayed primarily by a percentage levied on the lunatic's net annual income, with incomes under $£ 100$ a year paying nothing, and with considerably reduced fees. And where a lunatic's property was less than $£ 700$ in capital value, or where his income was $£ 50$ per annum or less, the estate could be exempted from both the fees and the percentage. ${ }^{56}$

These procedural reforms to the inquisition applied to all Chancery lunatics, and not to small estates in particular, but they undoubtedly helped the latter to bear the costs of an inquisition and thereby permitted greater access to judicial protection. The length of the inquisitions was reduced from weeks to days, jury trial was reduced to a minimum, the number of petitions, orders and reports halved, and the expense reduced by a third. So by the late 1850 s an uncontested lunacy inquisition relating to a small estate of $£ 1,400$ would cost just over $£ 200$, though could be as low as $£ 40$ in the case of the smallest estates, ${ }^{57}$ a sum which fell to some $£ 15$ in the early years of the twentieth century. ${ }^{58}$ The procedural reforms were justly welcomed as a significant improvement in the law $^{59}$ and were said to have "given satisfaction to all persons in the profession". ${ }^{60}$

\section{The Legislative ResPonse}

Though reduced, the cost of securing the court's protection of the property of the mentally ill was still material and for very small estates amounted to "a grievous hardship". ${ }^{11}$ The Lord Chancellor had no jurisdiction over lunatics not so found by inquisition ${ }^{62}$ and so had no power to assist lunatics of small estate who could not afford the costs of the process. What was necessary was substantive legislative reform providing a specific legal regime unambiguously directed to protect small estates.

The legislative response was initially slow and limited. The first substantive reform was perceptive to the extent that it made use of the bureaucratic organ, the Lunacy Commissioners, and their wide knowledge of individual lunatics detained in an institution yet currently outside the protection of the Lunacy Court. If they learned, through information from family or friends, or from the lunatic himself, that

$5516 \& 17$ c. 70 , ss. 42,44 . A jury would be summoned if the patient or court wished: ibid., sections $41 ; 43$.

56 Ibid., sections 26, 29, 32 .

${ }^{57}$ S.C. Lunatics 1859 , qq. $1310-13$.

${ }_{58}$ R.C. Feeble-Minded 1908 (4218), qq. 29292-98; R.C. Feeble-Minded 1908 (4215), q. 3003.

${ }^{59}$ H.L. Deb. ser. 3 vol. 126 col. 1221 (6 May 1853).

${ }^{60}$ The Times 31 March 1852.

61 "Lunacy", (1852) 16 Law Review \& Quarterly Journal of British \& Foreign Jurisprudence 190, 197.

${ }^{62}$ Re Ridgway (1828) 5 Russ. 152; Bishop of Exeter v Ward (1833) 2 Myl. \& K. 54; Re Bligh (1879) 12 Ch. 364, 365; Vane v Vane (1876) 2 Ch. D. 124. 
the patient's property was not being properly protected, or the income arising from it was not being used for the patient's maintenance, they were empowered to report to the Lord Chancellor who could then order an inquiry, appoint a receiver of the estate, order the application of the lunatic's income for his maintenance and invest any surplus for the patient's use. ${ }^{63}$ The Lunacy Commissioners used their reporting powers extensively, revealing a significant number of instances of abuse of small estates. ${ }^{64}$ Given the primary role of the commissioners in regulating lunatics who had been detained under certificates and reception orders, the reporting provisions were implicitly, though not expressly, directed towards the protection of the property of poor and middle class patients. While the process ensured, as never before, that abuses of such lunatics' income were brought to official cognisance, and the initiation of proceedings was cheaper than by the traditional full inquisition, beyond that the patient simply entered the existing judicial process of inquisition, which was left as expensive, slow and formal as before. It was, consequently, of limited assistance to poorer lunatics and as such was subject to widespread criticism. Only two years after the provision was first enacted, the Lunacy Commissioners condemned both its substance and its operation saying that it was practically unavailable to patients of modest means. ${ }^{65}$ Another forceful and influential critic, representing both the professional and public sectors, was the Law Amendment Society. It exposed the full expense of the process, called for greater protection of the lunatics' capital, and demanded the restitution of the correct principle of legal theory that the Lord Chancellor should protect the property of all lunatics, large or small. ${ }^{66}$

The second substantive legislative reform for the protection of small estates adopted a more orthodox approach and yet one which was novel in the context of lunacy and was to prove of lasting significance. Legislation in $1862^{67}$ built on an earlier provision of $1853^{68}$ to establish a cheap and summary method whereby the property of lunatics could obtain the protection of the Lunacy Court. In so doing it also addressed the deficiencies of the reporting process of 1845 . It provided that where a person was established as a lunatic, whether under the jurisdiction of the Lord Chancellor or the regulation of the Lunacy Commissioners, and his property did not exceed $£ 1000$ in value or a

\footnotetext{
${ }^{63} 8 \& 9$ Vict. c. 100 , ss. 94,$95 ; 16$ \& 17 Vict. c. 70 , s. 54.

${ }^{64}$ Report of the Lunacy Commissioners to the Lord Chancellor, HCPP 1846 (C. 471) xxxiii 339, 340; Further Report Lunacy 1847-8, pp. 406-7; HCPP 1862 (C. 509) xliv 547. For detailed examples see S.C. Lunacy Law 1877, qq. 9384-9409; Lunacy Commissioners 17th Report, HCPP 1863 (C. 331) xx 437.

${ }_{65}$ Further Report Lunacy 1847-8, p. 406.

66 "Reports of the Society for Promoting the Amendment of the Law" (1848-49) 9 Law Review \& Quarterly Journal of British \& Foreign Jurisprudence 313, 321.

${ }^{67} 25$ \& 26 Vict. c. 86 , s. 12.

${ }^{68} 16 \& 17$ Vict. c. 70 , s. 120.
} 
yearly income of $£ 50,{ }^{69}$ the Lord Chancellor could make the property available for the patient's benefit or maintenance. It could be sold and the proceeds paid to a relative or other proper person to apply under the court's direction. ${ }^{70}$ At first the provision applied only to lunatics so found, with the continuing prohibitive expense and formality of that process, and as such was of limited assistance to those lunatics with small principal sums or annuities, or small interests in land. But when the Act of 1862 provided that no inquisition was required ${ }^{71}$ it constituted the first step in providing effective and accessible judicial protection for the small estates of the mentally ill. ${ }^{72}$ As the Lord Chancellor had the same powers as if the lunatic had been so found by inquisition, the Act in effect created a quasi-Chancery lunatic under a special jurisdiction to provide for maintenance. ${ }^{73}$ Although there were initially some doubts as to the effectiveness of the court's control of the receiver, ${ }^{74}$ and a recognition that the smallest estates remained unprotected ${ }^{75}$ the provision came to be widely used. It formed the basis of a similar provision in the major consolidating and amending statute of $1890,{ }^{76}$ and as such formed part of the legal regime in lunacy for the next seventy years. The process was simple, cheap and effective, costing just a few shillings if applied for without professional assistance, ${ }^{77}$ and for very small properties of less than $£ 700$ in value or $£ 50$ yearly income only a simple letter to the master was required and fees were remitted. With realistic financial limits and a liberal judicial construction, ${ }^{78}$ it was a very popular form of protection that was "greatly appreciated by owners of small property" 79 and effectively drove the inquisition out of the market. ${ }^{80}$ Records of the Lord Chancellor's department show that it brought within his protection a great many lunatics with small annual incomes, some as low as $£ 25$ and most at some $£ 300 .^{81}$

The evidence shows that the Victorian legislature responded actively and positively, if slowly, to the challenge of protecting the increasing number of lunatics of small estate. The first reforms undoubtedly assisted the very wealthy and the more affluent middle classes by reducing the expense of the inquisition, but the amending

69 The limit was raised in 1882 to $£ 2000$ capital or $£ 100$ a year in income: $45 \& 46$ Vict. c. 82 , s. 3 .

7025 \& 26 Vict. c. 86 , s. 13.

71 Harvey $v$ Trenchard (1864) 34 Beav. 240.

72 Theobald, Lunacy, p. 76.

73 S.C. Lunacy Law 1877, qq. 10704-21; TNA MH 51/54.

74 Theobald, Lunacy, p. 76.

75 Lunacy Commissioners 24th Report, HCPP 1870 (C. 340) xxxiv 1, 63.

7653 Vict. c. 5, s. $116(1)$ (e); s. $116(2)$, (3); 8 Edw. VII c. 47, s. 1.

77 Report of the Royal Commission on Lunacy and Mental Disorder, HCPP 1926 (Cmd. 2700) xiii $373,530-31$

78 Re Adams (1864) 9 L.T. N.S. 626; Re Faircloth (1879) 13 Ch. D. 307.

${ }^{79}$ R.C. Feeble-Minded 1908 (4202), para. 762, p. 444. See too TNA LCO/10/13.

${ }^{80}$ R.C. Feeble-Minded 1908 (4215), q. 3006 per T.H. Fischer, master in lunacy. By 1922 it was described as 'moribund': Theobald, Lunacy, p. 80.

81 TNA LCO 10/12; TNA LCO 10/13. 
and consolidating legislation of 1889 to 1891 made the care and control of the court available to all mentally ill patients, whatever the size of their property, and in effect removed the distinction between all categories of the mentally ill with respect to the quality of legal protection they enjoyed for their property. When the capital and income of the mentally ill were secured by the law outside the formal inquisition process, and those safeguards were affordable and robust, adequate legal protection for the middle class and poorer lunatic population had been achieved.

\section{The JUdicial SOLUTION}

Analysis of the legislative response to the challenge posed by the increase in mental illness among the middle classes confirms that there was an extensive and effective recasting of the legal regime to afford appropriate protection of patients' property, but it reveals that it maintained the Lord Chancellor's procedures and jurisdiction in the Lunacy Court as its essential and central framework. The procedural reforms did indeed make the inquisition process less expensive and more informal, but it remained entirely a court process. The Lunacy Commissioners' power to report on the suspected abuse of property did no more than to provide a simpler and cheaper process whereby the judicial authority was alerted to the abuse. When the matter subsequently became one of receivership, both under that power and in the 1890 Act, that was a process as much under the control of the court as the inquisition process was. The judicial solution to the challenge of the growth in the number of lunatics of small estate was unequivocally adopted and implemented in the lunacy code of the nineteenth century.

That the judicial solution should be adopted was never seriously questioned, and the evidence reveals a clear, continuous and fundamental refusal to conceive of any means of protection other than through the judicial authority in the form of the Lunacy Court. It was almost universally accepted that a court of law, and specifically the Lunacy Court, could not be bettered in principle as the organ of protection of property. This view was consistently maintained. In 1860 Lord Shaftesbury, chairman of the Lunacy Commission since 1845, acknowledged that the Lunacy Court's masters were "the superintendents of property", ${ }^{82}$ and in 1877 , when the amalgamation of certain aspects of the work of the commissioners and the court was proposed, it was never doubted that the best possible protection for a lunatic's property, and the only appropriate one, was the Lord

${ }^{82}$ Minutes of Evidence before the Select Committee on Lunatics, HCPP 1860 (C. 495) xxii 349, q. 415 [hereafter, S.C. Lunatics 1860]. 
Chancellor in his court. ${ }^{83}$ In 1906 a lunacy master said the court did the best it could with small estates and made them go as long possible for the benefit of the patient. ${ }^{84}$ And although in 1908 the transfer of the lunacy jurisdiction to the Chancery Division of the High Court was recommended, a far-reaching and important proposal, it was not a jurisdictional change with respect to the property of the insane, merely an internal reorganisation within the judicial framework. ${ }^{85}$ The conviction that jurisdiction over lunatics' property, large and small, should be kept exclusively in the hands of the regular courts, which were accustomed to the work and could address it efficiently and expeditiously, was unshaken. The notion of judicial protection through a specialised court was dominant, and none other was seriously envisaged despite undoubted problems of expense, delay and inaccessibility. Trenchant and deserved though the criticism of the Lunacy Court's processes was, the consensus was that the principal deficiencies in the process had been addressed and that the substance of the protection afforded once the process was complete was excellent and provided the proper and most effective safeguard possible. It was said that the court's protection of lunatics would "always redound to its honour", ${ }^{86}$ and contemporary commentators referred to its "pitying paternal jurisdiction" ${ }^{87}$ and the "excellent keeping" it afforded the affairs of lunatics. ${ }^{88}$

This retention and reinforcement of the Lunacy Court as the only organ for the protection of the property of the mentally ill is a striking and essential feature in the legal history of insanity. It is conspicuous because the court was always regarded as the best organ of protection for lunatics' property - as indeed it was, for wealthy lunatics - even where there existed clear, serious and apparently intractable problems of accessibility that needed to be resolved if the challenge of the increasing numbers of lunatics of small property was to be met. On those grounds alone it raises the issue why the court was retained. It is, however, an issue that resonates beyond the internal history of the court when it is considered that the court's specific shortcomings were set within a wider context of antagonism and vulnerability which potentially threatened the existence of the court itself. During the crucial formative years of the legal regime in lunacy from 1845 to 1890, the Lunacy Court operated in a political climate of considerable hostility, arising from the potency of two ideological movements which dominated nineteenth century law-making: state intervention and the rationalisation of the legal system.

${ }^{83}$ S.C. Lunacy Law 1877 , qq. 9462-65.

${ }^{84}$ R.C. Feeble-Minded 1908 (4218), q. 30278.

${ }_{85}$ R.C. Feeble-Minded 1908 (4202), para. 805.

${ }^{86}$ (1894) 10 L.Q.R. 12.

${ }^{87}$ (1898) 14 L.Q.R. 226.

${ }^{88}$ (1899) 15 L.Q.R. 4. 
It has been seen that a common response of the Victorian state to the most serious and widespread social issues was to impose powerful central government control by establishing a new statutory bureaucratic body to implement a programme of reforming regulatory legislation, and that this model had been adopted in numerous fields of social concern, including lunacy. In some such instances, and to differing extents, the jurisdiction of the regular courts was eroded and elements of it directed to new statutory organs of the executive with simple, cheap and accessible procedures dealing with small cases, whether they were adversarial or investigative. Taxation, railways, a host of local government matters, tithes, copyholds and inclosures were addressed in this way contemporaneously with the state intervention into lunacy. ${ }^{89}$ This new and widespread practice of using organs or officers of the executive to undertake duties which had hitherto been - or could potentially be - the responsibility of the regular courts of law, constituted an obvious undermining of the role of the judges..$^{90}$ Even in those fields of activity where the judges were content to allow organs of central government to restrict their role, often because they did not want to become involved in what they regarded as mere administrative regulation, ${ }^{91}$ the perception that the government was attempting to confine the role of the courts could be unpopular. ${ }^{92}$ The judges of the Lunacy Court were inevitably aware of these movements and were naturally alive to the potential consequences for their court. The Lunacy Commission was indisputably an organ of central government control, ${ }^{93}$ albeit an atypical one in terms of its powers, discretions, development, attitudes and political accountability. ${ }^{94}$ Its introduction marked a clear shift of power from an exclusively judicial control of lunacy to a degree of executive control, embodied in the emergence of this new and powerful organ with responsibility for the vast majority of lunatics. The creation of such an organ in a context where bodies of a similar character in other fields were encroaching on the traditional work of the regular courts, contributed to a political context hostile to the Lunacy Court.

${ }^{89}$ See generally R.E. Wraith and P.G. Hutchesson, Administrative Tribunals (London 1973), 23-28; Chantal Stebbings, Legal Foundations of Statutory Tribunals in Nineteenth Century England (Cambridge 2006), 1-72.

90 See "Introduction" to "English Law in Industrializing Society" in Cornish and others, Oxford History of the Laws of England, vol. 11, 525-27.

${ }^{91}$ For judicial attitudes to railway regulation see Stebbings, Legal Foundations of Tribunals, pp. 54 5.

92 See an important later example in planning law: Cocks, "Statutes, Social Reform, and Control", pp. 595-96.

93 Mellett, "Bureaucracy and Mental Illness", p. 224.

${ }^{94}$ Professor Anderson has described it as a 'strange semi-executive, semi-advisory body': Stuart Anderson, "Central Executive: The Legal Structure of State Institutions" in Cornish and others, Oxford History of the Laws of England, vol. 11, 357; Mellett, "Bureaucracy and Mental Illness, pp. $242-44$. 
The Lunacy Court was also vulnerable to the movement for the reform of the law and legal process which had as its central objective a uniform, efficient and rational legal system. That movement included two features of particular significance to the Lunacy Court: an unambiguous commitment to abolishing all specialist jurisdictions in independent courts ${ }^{95}$ and a determination to reform the procedures in all the regular courts to ensure speed and simplicity. ${ }^{96}$

The Lunacy Court clearly exercised a specialist jurisdiction, and was therefore vulnerable to the orthodox view that specialist jurisdictions undermined the organisation, order, classification and efficiency that characterised a rational legal system. The Judicature Commissioners in the latter years of the nineteenth century wanted to address the overlapping, conflicting, uncertain or anachronistic specialist jurisdictions which made a litigant's life a misery and to propose reforms which would ensure the speedy and economical dispatch of judicial business. They sought a more uniform and consistent system. While the hostility towards special jurisdictions was directed primarily at local courts, there was a pervasive and official anxiety that specialisation could be taken too far within the regular court system. This led the Royal Commission on the Care and Control of the Feeble Minded in 1908 to recommend that in the interests of increased efficiency and economy the lunacy jurisdiction exercised by the Lunacy Court be transferred to the Chancery Division of the High Court, and that the office of master in lunacy be abolished. ${ }^{97}$ The arguments were persuasive and cogent. Not only was the workload of the Chancery Division decreasing, and that of the Lunacy Court increasing, the business of the latter in caring for the mentally ill was closely analogous to the former's work in caring for infants, and the superior processes and practices in the Chancery Division meant that it carried out its duties in this respect with far more speed and efficiency than the lunacy judges and officials. This was due to the Chancery judge enjoying a large staff under his control, a control that the judge in lunacy did not possess over the masters in lunacy, and the practice of judicial sittings during the vacations. Furthermore, it was absurd for the increasing amount of trustee work, where a trustee became lunatic and legal arrangements such as the appointment of new trustees and the execution of vesting orders needed to be made, to be conducted by the Lunacy Court, as it was properly a matter for the Chancery Division.

The movement for the reform of court procedures was equally hostile to the Lunacy Court. The provision of cheap, fast and effective

95 Judicature Commissioners 2nd Report, HCPP 1872 (C. 631) xx 217.

${ }_{96}$ Judicature Commissioners 1st Report, HCPP 1868-69 (C. 4130) xxv 1

97 R.C. Feeble-Minded 1908 (4202), para. 805; R.C. Feeble-Minded 1908 (4218), qq. 28373-82, 29248. 
justice was a political imperative for the Lord Derby's Conservative ministry ${ }^{98}$ when popular demand for law reform reached its height in the middle years of the nineteenth century, and one to which Lord St Leonards was strongly committed, both in general and specifically in relation to lunacy. As a result, procedures in all the courts of law were being examined. In the extensive discussions of urgently-needed reform of the processes and organisation in the Court of Chancery in the first half of the nineteenth century, questions which in principle could affect the perception of the court's lunacy work were raised. The technicality, cost and extreme slowness of Chancery procedures were the subject of informed and popular criticism, not least through the accurate portrayal of the suit of Jarndyce v Jarndyce in Charles Dickens' Bleak House in 1853. Contemporary commentators complained of the "tragedy of a Chancery Suit" and a process that was "incongruous, tortuous, and mischievous". ${ }^{99}$ Procedures in the Lunacy Court were, if anything, even worse in these respects. The processes were archaic, technical, opaque and slow and suited mainly to the wealthy. And when Chancery processes were used in the post-inquisition stage, they were ill-suited in that they were designed to deal primarily with hostile litigant parties and to implement clear rights or processes, whereas in lunacy there was no litigation in the usual sense of the term, and the law was paternal and protective. The supervision of lunacy by the Lord Chancellor, the use of Chancery processes in the administration of estates subsequent to the inquisition, continuing Chancery traditions and the widespread use of the term "Chancery lunatic" to describe lunatics so found by inquisition, strongly linked the Lunacy Court to the Court of Chancery in the public mind. The former was clearly tainted by the faults of the latter and that factor contributed to its vulnerability. Furthermore, although the problems of delay and expense which placed the early nineteenth century Chancery Court in crisis were ultimately solved by procedural reform and increased staffing, ${ }^{100}$ it is clear that pressure of business in the court was identified as a problem and the question of removing business was frequently raised. ${ }^{101}$ It was early recognised that lunacy was a time-consuming area of work within the Court of Chancery, for both the masters and the Lord Chancellor. That, combined with a lack of coordination and fragmented

98 “Lord Derby's Policy as to Law Reform” (1852) 16 Law Review and Quarterly Journal of British and Foreign Jurisprudence 1.

99 "The First Report of the Chancery Commissioners" (1852) 16 Law Review and Quarterly Journal of British and Foreign Jurisprudence 115. See Michael Lobban "Preparing for Fusion: Reforming the Nineteenth-Century Court of Chancery, Part 1' (2004) 22 Law and History Review 389, 39197; and generally Patrick Polden, "The Court of Chancery, 1820-1875" in Cornish and others, The Oxford History of the Laws of England, vol. 11, 646-91.

${ }^{100}$ Michael Lobban, "Preparing for Fusion: Reforming the Nineteenth-Century Court of Chancery, Part 2" (2004) 22 Law and History Review 565, 574-79; 582-84.

${ }^{101}$ Lobban, "Preparing for Fusion Part 1", pp. 398-409. 
responsibilities identified within the Court of Chancery in relation to lunatics, ultimately led to the complete separation of the work into a distinct Lunacy Court in 1842. Lunacy work was thus kept within the judicial system, but its recognition as an onerous and discrete area of work that could be detached in this way rendered it more vulnerable to later reassignment in principle.

In this interventionist and reformist context, the adoption of an exclusively judicial solution to the challenge of lunatics' small estates was a singular achievement, but the survival of the Lunacy Court as its specific instrument was remarkable. Not only did that court ensure that the lunacy jurisdiction was retained in the hands of a judicial authority, it also managed to keep its identity as a completely discrete department of the Court of Chancery in virtually all lunacy matters to administer it. It successfully overcame the legal system's hostility to specialist jurisdictions and its determination to introduce uniform procedures, affirmed the need for judicial regulation of lunatics' property and justified the single-minded exclusion of any additional or alternative organ of management and protection. That it retained its position as the proper and sole organ for the protection of the property of the mentally ill was due to the independence, resilience, astuteness and determination of the nineteenth century Lunacy Court.

For over fifty years the judges, masters and visitors of the Lunacy Court were "strenuously of opinion that their isolated position should remain unimpaired" and that the "judicial machinery should not be touched". ${ }^{102}$ This was so even in areas which did not touch upon patients' property. In the late 1850 s the transfer of some of the Lunacy Court's responsibilities for the person of Chancery lunatics to the Lunacy Commissioners was discussed and despite some strong support for the proposal, it was not effected. ${ }^{103}$ In 1877 even a minor degree of amalgamation with the Lunacy Commissioners in relation to the visitation of patients was opposed. ${ }^{104}$ In 1908 when the transfer of the jurisdiction of the masters and judges in lunacy to the Chancery Division, a mere internal reorganisation, was recommended, ${ }^{105}$ it was not acted upon. And though the Lord Chancellor was given the power in 1890 to amalgamate the masters, Chancery visitors and the Lunacy Commissioners, and its exercise was recommended in 1908, he never did so. ${ }^{106}$ The personnel of the court made powerful and persuasive arguments for their supremacy in property matters to both the government and the public, and were proactive in safeguarding their

102 R.C. Feeble-Minded 1908 (4202), para. 782.

${ }^{103}$ S.C. Lunatics 1860 , pp. 361-62.

${ }^{104}$ S.C. Lunacy Law 1877 , qq. 6884-92; 9461-66.

${ }^{105}$ R.C. Feeble-Minded 1908 (4202), para. 811.

10653 Vict. c. 5 s. 337; R.C. Feeble-Minded 1908 (4202), para. 805; Royal Commission on the Civil Service, HCPP 1914-16 (Cd. 8130) xii 91, qq. 48317-28; 50604; Appendix xcl. 
inherent jurisdiction. This suggests that they understood the need to assert themselves to maintain their position, and that the distinctiveness and importance of their traditional role in the protection of property could prevent their court being subsumed into the Chancery Division or encroached upon by the bureaucratic regime of lunacy regulation.

The Lunacy Court clearly had intrinsic advantages which it promoted strongly in legal and political circles and which it pointedly emphasised in parliamentary debate, official inquiries and the press. ${ }^{107}$ It possessed the necessary organisation and machinery to ensure that the property of the mentally ill, whatever its size, was protected so that it was used only for the patients' care and preserved for their recovery, with all expenditure accounted for. Although the court had been left behind in the major restructuring of the legal system in the 1870s, partly as a result of its measure of independence within the Court of Chancery, and its procedures had not been fully reformed, there had been some improvements to meet popular demands, notably the simplification of the inquisition process and the introduction of receivership. The lead taken by the judges in calling for these genuinely beneficial reforms and their subsequent enactment signified that the judges in lunacy were open to criticism and willing to co-operate with the new climate of law reform. The court also enjoyed the significant advantage in pragmatic and cost-conscious government circles of being self-supporting, as it was financed entirely by fees and the lunacy percentage. It also showed itself willing to retain the management even of small estates, despite their troublesome nature to supervise, especially where they consisted of small businesses which had to be managed or wound up, or where an estate was in disorder and litigation was necessary to sort it out.

That it was a court of specialist jurisdiction was impossible to contest, but the judges and masters of the Lunacy Court defended themselves robustly on the grounds of a need for specialist expertise in such a substantively technical and esoteric branch of the law, a perception that the inaccessibility of the law reinforced. They convincingly maintained that a specialist jurisdiction dedicated to the protection of the insane, with unrivalled expertise and understanding of a difficult condition and its consequences, was essential to successful protection of the property of the mentally ill. This was a powerful argument, sufficiently so for the Lunacy Court successfully to elude the contemporary official opposition to specialist jurisdictions. When questions of amalgamation of the different departments or a transfer of jurisdiction to the Chancery Division arose, a repeated objection was that lunacy was

${ }^{107}$ As with Lord Lyndhurst's discussion of the lunacy issue in The Times 31 March 1852. 
such a specialised branch of law that it should be kept in a dedicated department, as a lack of expertise and experience would cause more delay and expense; indeed it would result in less efficiency not more. ${ }^{108}$ For the same reason the County Court was rejected as a major recipient of the lunacy jurisdiction. ${ }^{109}$ When the Lunacy Court agreed to the transfer of limited functions to the Chancery Division, ${ }^{110}$ it was a pragmatic concession which did not undermine the main thrust of the judicial response to possible threats to its jurisdiction.

The Lunacy Commission constituted an obvious competitor. The possibility of tension and conflict between the two bodies, though working in the same field of activity, was clear. And yet the Lunacy Court was able to maintain its position in relation to the Lunacy Commission and avoid being undermined by it, primarily and precisely by using the different objectives, functions and cultures ${ }^{111}$ of the two institutions to its advantage and thereby diffusing any potential conflict on the question of property. The Lunacy Court effectively demonstrated its unrivalled suitability for the protection of property. A measure of its success was that despite the history of provision for the mentally ill in the modern era being one of increased legislative regulation effected through organs of central government, and notwithstanding the Lunacy Commissioners' undoubted independence, knowledge and experience, they were never seriously considered as a suitable alternative to the court for the protection of property. When in 1860 the Select Committee on Lunatics discussed the transfer to the Lunacy Commissioners of responsibility for Chancery lunatics, it was only their treatment and general supervision that were considered. There was no question of transferring any jurisdiction over lunatics' property from the judicial to the bureaucratic authority. When the Lunacy Commission was replaced by the Board of Control in 1913 as the authority of central government in lunacy regulation, ${ }^{112}$ no changes of principle were made in relation to the protection of lunatics' property: the judicial solution remained the only one.

The reasons why the Lunacy Commissioners were never considered as suitable for the protection of the property of the mentally ill were several. The commission was created as an advisory body, without executive functions. The commissioners inspected, commented, recommended, revealed abuses and spread good practice, and in this their influence was profound, ${ }^{113}$ but from their inception they were denied any powers to protect the property of lunatics not so found by

${ }_{108}$ R.C. Feeble-Minded 1908 (4218), qq. 29445-47.

${ }^{109}$ Ibid., qq. 30100, 30109.

${ }^{110}$ Namely vesting orders where lunatics were involved.

111 See generally Mellett, "Bureaucracy and Mental Illness".

$1123 \& 4$ Geo. V c. 28, ss. 21, 22.

113 Mellett, "Bureaucracy and Mental Illness", pp. 244 45. 
inquisition. They themselves accepted the perception of the court as the proper protector of lunatics' property, and their own chairman said that they should not "trench upon [the court's] rights" as such. ${ }^{114}$ They admitted their lack of experience and knowledge of the administration of property, and the widely accepted view was that to give the commissioners the power to deal with lunatics' property would lead to confusion and tend against economy. ${ }^{115}$ It was also generally acknowledged that the commissioners had extensive and expanding duties leaving no spare capacity for any new responsibilities. ${ }^{116}$ The commission's constitution, its members' own diffidence, and the tacit acceptance by the court that the commission was better equipped to protect the persons of certified lunatics in state asylums, combined to avoid any undue impact of state intervention on the exercise of the Lunacy Court's jurisdiction.

In maintaining its role as protector of the property of incapacitated individuals in the face of the Lunacy Commission, the court's determination resonated with contemporary public concerns. The overall context of all centralising reforms in the nineteenth century was essentially one of resistance to state intervention into the private affairs of individuals, and a distrust of the executive. ${ }^{117}$ It was regarded as an un-English restriction of personal freedoms, and most notably an undermining of fundamental values, particularly those of localism and laissez-faire. While lunacy reform had not escaped such resistance, notably from the medical profession, ${ }^{118}$ it had been largely addressed within the legislative regime, and did not materially restrict the centralising reforms. However, enduring popular attitudes to the sanctity of private property proved potent in ensuring that the protection of lunatics' estates remained a matter for the Lunacy Court. The early Victorians maintained the traditional and absolute view of property as the highest right it was possible to have in anything, with the right to exclude everyone else, including the state, from its enjoyment. Indeed, state interference with private property was regarded as permissible only if accompanied by full and fair compensation. ${ }^{119}$ Private property was not immune from executive interference in the nineteenth century, as can be seen, for example, from the recasting of private property rights in the commutation of tithes, the enfranchisement of copyhold land and the inclosure of common land in the 1830s and 1840s, and the undermining of property rights inherent in the public health legislation

\footnotetext{
114 S.C. Lunatics 1860, q. 415 per the Earl of Shaftesbury.

${ }^{115}$ R.C. Feeble-Minded 1908 (4218), q. 28464.

116 Mellett, "Bureaucracy and Mental Illness", pp. 226, 230-34, 240.

${ }_{117}$ Roberts, Victorian Origins, pp. 22-34; 95-104.

118 Mellett, "Bureaucracy and Mental Illness", pp. 239-40.

119 Sir William Blackstone, Commentaries on the Laws of England (Reprint of 1783 edition, New York 1978) vol. 1, 138-40. See London and North Western Railway v Evans [1893] 1 Ch. 16, 28.
} 
later in the century. Such interference, however, was strongly resented beyond the undermining of vested interests. ${ }^{120}$ There was a general disinclination to commit private property to the management of an organ of central government, and this left the way clear for the Lunacy Court to stake its claim to the exclusive protection of lunatics' estates. Furthermore, the safeguarding of private property by the Lunacy Court to a large extent neatly bypassed contemporary concerns as to the undermining of traditional paternalistic social attitudes in relation to the formulation of a regime for the regulation of lunatics, ${ }^{121}$ as the jurisdiction of the Lunacy Court was recognised as being intensely paternal in nature and, moreover, emphasised the importance afforded to private property rights.

Beyond astutely engaging with the political imperatives of law reform and state intervention as far as it could, the Lunacy Court asserted its position by proactively and strongly defending its own inherent jurisdiction, which had always been perceived principally in terms of property. The judges' awareness of their vulnerability, and the steps they took to address it, were demonstrated by the decision in $R e$ Earl of Sefton in 1898 in which a lunatic sought permission to alienate a very small portion of his estate in order to safeguard the whole, much larger, portion. ${ }^{122}$ The court there directly addressed the juxtaposition and interrelationship of the two strands of jurisdiction, inherent and statutory, and affirmed its position primarily by adopting a flexible approach to its interpretation of the statutory lunacy code. Instead of taking the traditional strict English approach to statutory interpretation, it preferred a liberal approach and looked to the overall purpose of the legislation. A strict construction of the statute De Prerogativa Regis, which was a prohibiting enactment, would have been fatal to the lunatic's claim. Instead the court adopted an unprecedented wide interpretation of the 1324 statute to ensure that its own ancient inherent jurisdiction was not inhibited, and a very narrow construction of the Lunacy Act 1890 to show that it did not apply in its terms to the situation then before it. In so doing the court held that the 1890 Act was merely declaratory of the ancient jurisdiction, that it was not exhaustive, and that it did not limit or curtail the inherent jurisdiction of the court. It was an enabling Act that did not supersede the inherent jurisdiction. The court thereby unambiguously asserted the existence,

${ }^{120}$ Roberts, Victorian Origins, p. 25; Lubenow, Government Growth, p. 89; Fraser, British Welfare State, pp. 61-3. For tithes, copyholds and inclosure, see Stebbings, Legal Foundations of Tribunals, pp. 92-93.

121 Though it has been argued that the eighteenth century paternalism expressed in minimal state intervention and robust local autonomy was replaced by one that saw government taking the place of family and community: Lawes, Paternalism and Politics, pp. 1, 2, 7. See too David Roberts, Paternalism in Early Victorian England (London 1979), 248.

${ }^{122}$ Re Earl of Sefton [1898] 2 Ch. 378. 
scope and vigour of its ancient inherent delegated jurisdiction in lunacy. This finding was possible precisely because the scope of the court's inherent jurisdiction had never been defined. This decision, striking within a remarkable paucity of case law in lunacy, affirmed the essential place of the Lunacy Court in the lunacy code and sent a clear signal to its critics that it was determined to retain it in its full vigour.

The Lunacy Court was astute in its self-promotion. In demonstrating the wide range and depth of its inherent jurisdiction it showed that where the statutory jurisdiction was inadequate in some way, as actually occurred in the Sefton case, the inherent jurisdiction could be called into play, and so "by hook or by crook almost any transaction which is for the patient's benefit can be sanctioned". ${ }^{123}$ The court portrayed its inherent jurisdiction as the real friend of the lunatic, the regime that enabled transactions to be effected for his benefit, and the court as the natural and most effective protector of his property, and indeed that in the field of property holding, the Lord Chancellor's protection was unsurpassed. In so doing, the court implicitly recognised the debate within lunacy law regarding the absence of any legal protection for the property of poorer lunatics, and reinforced an awareness that a significant growth in the number of individuals officially recognised as insane demanded clear and robust provision for the safeguarding of their property.

\section{CONCLUSION}

The modern legal framework for the protection of the property of the mentally ill was created in the Victorian period, when the arguments for adopting and reinforcing the judicial solution were accepted, implemented and embedded in the legal regime for lunacy. The challenge to the legal order was considerable; the easy and obvious solution was a bureaucratic one, but the exclusivity of central executive control was curbed, and the solution that was adopted, retained and reinforced was the judicial one. And, furthermore, it was established in the form of a specialised court of law. The evidence shows that the ancient jurisdiction of the Lord Chancellor in lunacy, while accessible to patients of small property in theory but not in practice, was in principle a highly effective organ of protection if the will to reform its procedural defects was present. The Victorian legislature responded, and over fifty years effected a gradual reform of the established inquisition process for the protection of all lunatics' property and introduced some substantive reforms specifically directed to accommodate small estates.

${ }^{123}$ Jennings, "Jurisdiction in Lunacy", p. $422 \mathrm{n}$. 
The development of a regime for the protection of small estates of the mentally ill was the product of a number of factors which came together with an unprecedented intensity in the nineteenth century. They included the need for state intervention; a popular distrust of the executive; the reforming agenda of the Victorian legislators in relation to the legal process; judicial conservatism; a complex branch of law dominated by practice; an archaic specialised jurisdiction; a new statutory jurisdiction; advances in medical science; the fundamental incapacity of the subjects of the law unable to articulate their needs and demands; powerful social, ideological and pragmatic forces; and, finally, strong, independent and articulate judges and masters. The interrelation of these factors created a momentum of its own, and revealed a number of imperatives, influences and attitudes, but the catalyst which produced a positive dynamic leading to a reformed legal regime for the protection of the property of the mentally ill was the determination of the Lunacy Court jealously to guard its jurisdiction over property and to ensure it was not violated either by the state apparatus or by another judicial body. Together they combined to resist any contrary forces and create a strong and accessible protection for small estates.

It has been seen that the substantive reforms for the protection of small estates were few and slow in coming. The evidence suggests four main reasons for this hesitancy. First, the commitment to resolving the specific problem of the smaller properties of the middle and working class mentally ill was subsumed by the overall movement to ensure that the judicial solution was the one adopted for the protection of all property. Secondly, the legislature had more pressing concerns to address in relation to lunacy, primarily to ensure that the population of pauper lunatics was protected from physical abuse and properly cared for and to do so by introducing a raft of legislation and the creation of a new bureaucratic body. Thirdly, while the public concern was indubitably with issues of personal liberty, it was directed not to the freedom to deal with property but to the liberty of the person and the possibility of wrongful detention of sane individuals as a result of the manipulation of the law by unscrupulous relatives and the law's inherent inadequacy in this respect. ${ }^{124}$ This imperative was regarded as of prime importance, and accordingly dominated over any concern for lunatic's property. And fourthly, the reforms were slow because, as a class, the mentally ill were a weak constituency. Due to their medical incapacity every aspect of the law and its administration was

124 Richard Saumarez, An Address on the Laws of Lunacy (London 1854), 1-2. S.C. Lunacy Law 1877, qq. 6899-7191. See too Peter McCandless, "Dangerous to Themselves and Others: the Victorian Debate over the Prevention of Wrongful Confinement" (1983) 23 Journal of British Studies 84; Mellett, "Bureaucracy and Mental Illness", pp. 241-42. 
determined by others in the perceived best interests of those subjected to it, with no articulation of their needs by the users themselves. As such, it was a supremely paternalistic branch of the law, and one which was highly susceptible to current social attitudes and medical theories. While the judicial protection of property was accessible to the wealthy Chancery lunatics, and their friends and families were generally in a position to articulate and press for any desirable legal reforms, and pauper lunatics were championed by the humanitarian and Evangelical forces within Victorian society and politics, the middle class lunatics of small property had no obvious lobby to ensure their particular position was not ignored.

While these four factors certainly hindered the speed of reform and the adoption of the judicial solution, they did not prevent it, partly because the issue of the protection of property was relevant to them all: it concerned lunatics who were paupers for the purposes of lunacy law but were not destitute; it was an aspect of personal freedom in the wider sense; and it undoubtedly directly affected wealthier lunatics who were subject to an unacceptably expensive system of protection. And, furthermore, the paternalistic ethos underlying the place of the mentally ill within English law strongly promoted a judicial solution to the legal protection of their small estates, primarily due to natural parallels drawn with the Court of Chancery's protective jurisdiction over infants. The increase in political power of the middle classes resulting from the broadening of the franchise and democratic representation in the early nineteenth century, and the increasingly obvious economic power of traders and industrialists considerably strengthened the position of the middle classes. Their increased confidence, eloquence and authority ensured their own particular concerns were heard.

The factor which could have entirely prevented the adoption of the judicial solution, namely the powerful ideology of state intervention, ultimately proved neither a viable competitor nor a material obstacle, but in 1845 it constituted a material challenge in principle to the Lunacy Court and a robust response and constant vigilance as to the erosion of its jurisdiction and position were required. The exclusion of the Lunacy Commissioners from any material involvement with lunatics' property and the recognition of the Lord Chancellor in the bureaucratic framework as the appointer of the commissioners and the formal recipient of their annual reports, served to diffuse any potential tensions and conflicts between the executive and judicial authority. Moreover, the authority given to the Lunacy Commissioners to report the abuse of lunatics' property to the Lord Chancellor and the latter's statutory power to protect the income of the lunatics in question and of lunatics of small estate in a summary way, provided for in the commissioners' founding Act and maintained in the lunacy code thereafter, 
showed that it was early understood that the statutory and judicial regimes in lunacy should not remain isolated from each other. The legislative response to the problem of small estates thus provided for such an interface and this contributed to the two frameworks, in theory at least, functioning smoothly together. As a result the interaction between the state's regulation of lunacy and the jurisdiction of the judicial authorities in relation to the property of the mentally ill was easy, at a time when fundamental principles of jurisdiction in this field of social and legal development were being formulated.

The decision in lunacy to use a judicial rather than an administrative body to address shortfalls in the protection of lunatics' property, even where the estate was small, is revealing as to the Victorians' attitude towards the boundary between the executive and the law. It confirms that government growth was not uniform, that different priorities characterised each area of reform, and that the balance between administrative and legal solutions adopted varied. Specifically, the evidence provides an insight into the judicial system's response to state intervention in the field of lunacy. It shows the judges were aware of the threat that state intervention could bring to even ancient established jurisdictions. It does not, however, show the judges to be a force that aimed to hinder centralisation in the nineteenth century; rather, that they were pragmatic, understood the need to effect major social reforms through legislation, and recognised they had to adapt and to work with the central authority. ${ }^{125}$ The judiciary's vested interests certainly marked the relationship, and the Lord Chancellor, judges and masters were clearly protecting their jurisdiction.

Judicial attitudes were a material factor in determining the final shape of the legal regime in lunacy: the Lunacy Court's refusal to contemplate any solution other than the judicial one for the protection, through close and personal management, of private property, and to maintain the inquisition when its abolition would have resulted in a simpler, more accessible and less anachronistic system, could be construed as judicial conservatism. For example, had the judges not waited until 1891 before agreeing that the masters be made judges of first instance with authority to make orders themselves, but had done so in the reforming legislation of 1853, the inquisition procedure would have been made instantly considerably more accessible. But the judges took the view that the masters should be kept under the court's control in order to ensure that they remained "active and diligent in the discharge of their duties." ${ }^{26}$ Such attitudes would suggest the mentally ill may

${ }^{125}$ William Cornish, "Government and People" in Cornish and others, Oxford History of the Laws of England, vol. 11, pp. 35-36.

${ }^{126}$ S.C. Lunatics 1859, q. 1316. See too S.C. Lunacy Law 1877, qq. 11154-55; Lunacy Act Amendment Act 1891, (54 \& 55 Vict. c.65), s. 27(1). 
have suffered as a result of judicial manoeuvring driven by the vested interests of the judges, either denying them effective protection or delaying its introduction. The response of the judges, however, could equally be described as judicial determination to maintain an ancient jurisdiction in the firm belief that it offered the best possible protection to the mentally ill, that it, with procedural reforms, constituted an effective response to the needs of poor and middle class patients, and recognised the public confidence in this solution.

Finally, the legal framework of lunacy law in relation to the protection of the property of the mentally ill is far more than an arid official aspect of the history of insanity. The attention of nineteenth century reformers and governments was directed to the pressing question of the management of pauper lunatics, and modern scholarship has concentrated on that discourse and its institutional implementation and social impact. ${ }^{127}$ This emphasis, together with a tendency to perceive the legal framework of property protection as relevant only to the small class of wealthy lunatics and as such of less importance to the dominant theme of state intervention in mental health, has left a void in scholarship which this paper addresses. This study has shown that in the nineteenth century the legal framework for the protection of property was a significant element within the political and public debate on the question of lunacy, and as a construct in its own right with its own tensions and dynamics, it was an important formative factor in shaping the policy with respect to the care of the mentally ill. The recognition that special compulsory powers were necessary to protect the property of patients when they could not manage their own affairs, ${ }^{128}$ that this protection should be easily accessible to the mentally ill with small properties, and that it should be implemented by a specialist court of law, prevailed with remarkable consistency throughout the nineteenth century and to the present day. ${ }^{129}$ The fundamental structure and authority of robust and highly accessible judicial protection with minimal or no jurisdiction over the person forms the core and imperative of today's legal framework for the care of the property of the mentally ill. ${ }^{130}$

${ }^{127}$ See e.g. Peter Bartlett, The Poor Law of Lunacy (London and Washington 1999); Joseph Melling and Bill Forsythe (eds.), Insanity, Institutions and Society 1800-1914 (London and New York 1999); Andrew Scull, The Most Solitary of Afflictions: Madness and Society in Britain 1700-1900 (New Haven and London 1993); Leonard D. Smith, Cure, Comfort and Safe Custody (London and New York 1999); Joseph Melling and Bill Forsythe, The Politics of Madness (London and New York 2006). See too Clive Unsworth, "Law and Lunacy in Psychiatry's 'Golden Age"', 13 Oxford Journal of Legal Studies 479.

${ }_{128}$ Royal Commission on the Law Relating to Mental Illness and Mental Deficiency, HCPP 1956-57 (Cmnd. 169) xvi 1, para. 136

${ }^{129}$ It was still the view in the 1930s: see Gerald E. Mills and Ronald W. Poyser, Lunacy Practice (London 1934), p. v; Mental Health Acts 1959, 1983.

${ }^{130}$ See Halsbury's Laws of England, 4th ed., vol. 30(2), paras. 672-764. 